\title{
The Potential of Bioeconomic Innovations to Contribute to a Social-Ecological Transformation: A Case Study in the Livestock System
}

\author{
Jonathan Friedrich ${ }^{1}\left(\mathbb{C} \cdot\right.$ Ingrid Bunker ${ }^{1}(\mathbb{1}) \cdot$ Sandra Uthes ${ }^{1}[$. \\ Jana Zscheischler ${ }^{1}$ (i)
}

Accepted: 30 June 2021 / Published online: 10 July 2021

(c) The Author(s) 2021

\begin{abstract}
Environmental crises, which are consequences of resource-intensive lifestyles and are characterized to a large extent by both a changing climate and a loss of biodiversity, stress the urgent need for a global social-ecological transformation of the agro-food system. In this regard, the bioeconomy and bioeconomic innovations have frequently been seen as instrumental in addressing these grand challenges and contributing to more sustainable land use. To date, the question of how much bioeconomic innovations contribute to sustainability objectives remains unanswered. Against this background, we study four bioeconomic innovations using the case study of animal production and manure utilization in relation to their potential contributions to a social-ecological transformation. The analysis is based on the application of analytical categories derived from the literature that assess the normativity of these innovations and their implicit cultural changes. The results show that the innovations examined manifest existing thought styles and the incumbent socio-technical regime rather than contribute to a more fundamental transition. In this respect, we stress the importance of evolving alterative ideas in innovation design, applying more integrative approaches, such as embedding innovation processes into transdisciplinary processes, and developing adaptive and reflective governance approaches. In return, bioeconomic innovations should adjust towards the design mission of a social-ecological transformation and include a multitude of actors to discuss and harmonize contesting imaginaries and ethical concerns.
\end{abstract}

Keywords Bioeconomy $\cdot$ Social change $\cdot$ Manure $\cdot$ Sustainability $\cdot$ Agriculture $\cdot$ Social sciences $\cdot$ Transdisciplinary

Jonathan Friedrich

jonathan.friedrich@zalf.de

1 Leibniz Centre for Agricultural Landscape Research (ZALF), Müncheberg, Germany 


\section{Introduction}

Agricultural landscapes in Europe and around the world are in transition. Climate change, urbanization, digitalization, and increasing societal demands for land and land-based resources drive and accompany these transition processes and will increase land-use competition in the future (Foley et al., 2011; Herrero et al., 2020; Hertel et al., 2013). In addition, many global sustainability challenges related to multiple crises, such as biodiversity loss, nutrient surpluses, soil degradation, greenhouse gas emissions, and environmental justice, are connected to agricultural landuse practices (e.g. Herrero et al., 2020; Temper et al., 2018; Tilman \& Clark, 2014; Tscharntke et al., 2012). This specifies the need for a social-ecological transformation (SET) at large.

The bioeconomy and according bioeconomic innovations have frequently been seen as a panacea by policy actors (Giampietro, 2019) in terms of addressing these grand challenges; these factors contribute to more sustainable land use (e.g., Bugge et al., 2016) and have been claimed to be important to at least half of the SDGs (United Nations Sustainable Development Goals) (El-Chichakli et al., 2016). These goals may be achieved through resource efficiency, fuel independence, and by following the contested vision of a green economy (e.g. Hickel \& Kallis, 2020; Loiseau et al., 2016) and the contested narratives of decoupling both economic growth from environmental degradation and the technosphere from the biosphere (e.g. Giampietro, 2019; Hickel \& Kallis, 2020).

However, the implied additional demand of a bioeconomy for renewable resources may lead to new ethical concerns and moral dilemmas that result from, e.g., an increasing competition for land and natural resources or the intensification of land use (such as through fostering monocultures); in addition, such demand may ultimately produce (new) target conflicts regarding the SDGs (e.g. Hertel et al., 2013) or even create new lock-ins or path dependencies (e.g. Klitkou et al., 2015). In general, the scientific knowledge about the potential risks and uncertainty associated with the complexity of a transition to the bioeconomy remains rather narrow (e.g. Bukkens et al., 2020). A significant example of this complexity is the food versus fuel conflict that resulted in increasing food prices during the so-called Tortilla Crisis in 2007/2008 (e.g. Tomei \& Helliwell, 2016); furthermore, bioeconomic policies may even foster land grabbing, which was found to be the case in sub-Saharan Africa (Ashukem, 2020). These risk examples related to food security and global price developments also reveal different vulnerabilities in society that raise new questions of social and environmental justice (Timmermann, 2020; Walker, 2012). In addition, socio-technical innovations and transition trajectories that are at the heart of a bioeconomic transformation may also shift environmental problems from one system to another or from one region to another (van den Bergh et al., 2015). Apart from this, the bioeconomy has been frequently criticized for its neoliberalization of nature at large and for following a "fossil logic" (e.g. Birch et al., 2010).

Against this background, it appears to be of central interest to clarify to what extent the development of a bioeconomy is compatible with the values and 
imaginaries $^{1}$ of a widely postulated SET. Both SET and the bioeconomy imply changes in human-nature relations and include tacit normative premises that form futures. However, a sustainability-oriented transformation is not granted but rather implies a design mission for a multitude of actors to transform the current agrofood system and the according land-use practices (Jahn et al., 2020). This process also raises numerous ethical questions as precise and normative objectives must be assessed and negotiated both before and after technological design, as "even modest technological improvements create new normative rights and obligations" (Jasanoff, 2016, p. 266). For a long time, the bioeconomy has been prevailingly considered from a technical-scientific and economic perspective, while little attention has been given to the social and cultural dimensions that reflect the main pillars of sustainability and the social science perspective at large (Sanz-Hernández et al., 2019). This lack of attention has led to the neglect of critically analysing the implicit normativity of the bioeconomy.

Although there is a clear political commitment to fostering a transition towards a bioeconomy on the part of many countries (El-Chichakli et al., 2016), it remains unclear whether bioeconomic approaches foster an SET that addresses the grand sustainability challenges of our time (Brand et al., 2020; Giampietro, 2019).

While Bröring et al. (2020) characterized bioeconomic innovations in regard to their suggested changes at the market level, the aim of this paper is to analyse the potential of currently developed bioeconomic innovations in contributing to SET, with a particular focus on changes at different scales, such as those made regarding the culture and organization of societies. We argue that SET entails changing values and norms in society. To examine the potential of bioeconomic innovations to contribute to SET, we thus apply central categories found in the SET literature to analyse the norms, values, and beliefs that are reflected and materialized in the innovation design of bioeconomic innovation. We exemplarily relate these categories to the German livestock system and, more specifically, to nutrient surpluses in the forms of manure, their complex global entanglements, and manure-based bioeconomic innovation. We discuss the origin of contemporary cultures of bioeconomic innovation design in society and how bioeconomic policies and research on bioeconomic innovation need to be adjusted to foster SET in the German livestock system.

\footnotetext{
${ }^{1}$ In the following, we refer to "imaginaries" as societally embedded and shared understandings and meanings that govern the way to societally desirable futures. In defining sociotechnical imaginaries, being part of the concept of imaginaries, we follow Jasanoff and $\operatorname{Kim}(2009$, p. 120), who refer to them as "collectively imagined forms of social life and social order reflected in the design and fulfilment of nation-specific scientific and/or technological projects". Jasanoff (2015) extended this definition by also accommodating visions of different groups of stakeholders or collectives in aiming to create a desirable future.
} 


\section{SET to Address Multiple Crises}

Against the backdrop of multiple ecological and social crises and the resulting sustainability challenges, the need for an SET has become increasingly invoked and is largely grounded in topics such as environmental justice or environmental ethics (Hölscher et al., 2018; Temper et al., 2018). Although there is not a single clear definition of the concept, an SET is frequently related to changes made to the complex interactions and interrelations between society and nature and the according social, cultural and ecological interlinkages (Moore et al., 2014). The debate is normatively interlinked with the integrative perspective of the sustainability discourse, and an SET can be seen as an approach that is multidimensional, global, and intersectional and thus transforms not only the economy but also society as a whole (Escobar, 2015; Stirling, 2014; Temper et al., 2018). Both an SET and a transformation towards a bioeconomy imply changes and transitions that are based on normative orientations and visions that mutually interact with norms, values and beliefs, as well as with rules and practices (Moore et al., 2014).

An SET is characterized as being driven by multiple values, norms, and imaginaries, which are often open to discussion. Brand et al. (2020) and Temper et al. (2018) argued that an SET must challenge the roots of contemporary ecological and social crises. In the literature on SETs, it has also been argued that an SET must integrate the complex relations in adaptive systems and overcome human-nature dualism (Brand \& Wissen, 2018), which is often done by using a complex socio-ecological systems approach (e.g., West et al., 2020). To frame contemporary crises, Brand and Wissen (2018) introduced the concept of the imperial mode of living, which integrates the complex global entanglements of capitalist societies. Following this argumentation, an SET is grounded in changing values and practices that move towards a solidarity mode of living (Brand \& Wissen, 2018), which the authors (ibid.) considered to be a de-commodification of nature and land, i.e., a "democratization of societal nature relations" (Brand et al., 2020) performed as a bottom-up approach. Social struggles and conflicts are seen as side effects that often strengthen radical change (Brand et al., 2020; Temper et al., 2018) and can accordingly be moderated as drivers of change.

However, as an SET is regarded as a democratic bottom-up approach that involves multiple actors, the normative dimensions of what to preserve ("target knowledge") and how to preserve it ("transformation knowledge") underlie constant negotiation processes and ethical reflections in society (Gorddard et al., 2016; O'Brien and Wolf, 2010; Pohl \& Hirsch Hadorn, 2008; Wiek, 2007; Max-Neef, 2005). Changes in values and norms can therefore indicate societal transformation processes (Moore et al., 2014), and changes at the socio-technical regime ${ }^{2}$ level (such as cultural and organizational) can be triggered by windows of opportunity and regime-niche interactions in socio-technical transition processes (Geels \& Schot, 2007). This also

\footnotetext{
2 The term "socio-technical regime" describes the present stable-dynamic combination of technologies, consumers, industry, and science in terms of activities and governing rules (for more details see Geels 2002; Geels and Schot 2007).
} 
refers to changes in innovation design, as described through the incorporation of novel actors and the challenging of incumbent structures and paradigms (Schlaile et al., 2017; Stirling, 2014).

\section{Socio-Technical Innovations in the Bioeconomy and the Contribution to SET-Developing Analytical Categories}

Innovations are considered a driving force of change and development in modern society. Whether for an SET (e.g. Brand \& Wissen, 2018; Bruckmeier \& Pires, 2018) or the bioeconomy (e.g. Jander et al., 2020; Strøm-Andersen, 2019), the design of innovations is discussed as having a key role. Beyond this design dimension, innovations can also have analytical and indication dimensions, as they make both social and socio-technical changes observable and therefore studiable.

Innovations and their evolutions follow specific thought styles or so-called sociotechnical imaginaries (Jasanoff, 2015). Policy strategies, such as the German bioeconomic strategy, function as documented sociotechnical imaginaries of the desired future (Giampietro, 2019). Sociotechnical imaginaries that become explicit in policy documents create implicit societal values and norms and can materialize in innovation. This process also becomes explicit in the characterization of innovation types in the bioeconomy from a market-centred perspective, which ultimately sees innovation as being societally desirable (Bröring et al., 2020).

In general, transformations refer to "radical, non-linear and structural change in complex adaptive systems" (Hölscher et al., 2018, p. 1) and can be considered "plural, emergent and unruly political re-alignments, involving social and technological innovations" (Stirling, 2014, p. 1). Thus, not every innovation may be societally desirable and contribute to a transformation.

Socio-technical innovations are also regarded as pivotal for a transformation towards the bioeconomy in Germany (BMEL [Federal Ministry of Food and Agriculture] and BMBF [Federal Ministry of Education and Research] 2020). We therefore argue that such innovations represent a comprehensive unit of investigation and serve as carriers of meaning for ongoing transformations. In our analysis, we thus focus on bioeconomic socio-technical innovations to study the complex processes of change towards a bioeconomy and to discuss the potential outcome for an SET. We follow the characterization of innovation types by Bröring et al. (2020) to define bioeconomic innovation and differentiate them from the broader topic of sustainability innovations.

We argue that the analysis of values and norms that influence innovation design allows us to determine the likelihood of bioeconomic innovations contributing to an SET. In return, this allows us to critically point out issues and gaps in innovation design and at the policy level of bioeconomic strategies.

Thus, to reflect current bioeconomic innovations and their potential contribution to, as well as their alignment with, a sustainability-oriented transformation, we have extracted the following central categories of an SET that are largely discussed in the literature to perform our analysis. 


\section{Aim of the Innovation}

The aim of an innovation reflects an envisaged future on the one hand and the means, instruments and ideas about how to achieve this future on the other hand (Jasanoff, 2015). In the discourse of transformative sustainability science, these two forms of knowledge are frequently named "target knowledge" and "transformation knowledge” (e.g. Pohl \& Hirsch Hadorn, 2008; Wiek, 2007; Max-Neef, 2005; O’Brien and Wolf 2010). Target knowledge represents normative knowledge and captures the desired goals and the needs and direction for change (know where?). Transformation knowledge incorporates support for the development of strategies for the societal transformation process and concrete action (know how?). This knowledge is also ultimately intertwined with values and norms that lead to specific decisions (Gorddard et al., 2016).

\section{Problem Framing and Solution}

The aim of an innovation is grounded in the framing of a certain problem. It can be argued that problem framing anticipates and shapes the solution (i.e., the innovation). Thus, the solution describes the socio-material answer to a perceived problem as the concrete "doing" (cf. Longhurst \& Chilvers, 2019) of the actors or actor collective. In discourses on the principles of an SET, it is commonly highlighted that many sustainability problems are highly complex, which points to a societal interest in the problem and an orientation to a "common interest" (Hirsch Hadorn \& Jäger, 2008). Often, the concrete definition of these problems is under dispute, shaped by uncertainty and interrelated with differing perceptions among distinct actors and interest groups (Zscheischler et al., 2017). As a consequence, actors (those involved in the innovation process) and their perception of the problem at hand and its origin define this framing. Individual perceptions and definitions of problems are driven by knowledge, societal perceptions and the framing of risks and problems. In the theory of science, these different perspectives on research topics/objectives of research are described by differing ontologies and epistemologies. This also means that societal and individual values and thought styles become reflected and incarnated in the concrete framing of problems and the doing of according solutions (Jasanoff, 2015; Longhurst \& Chilvers, 2019).

\section{Involved Actors}

Theoretical considerations on innovation processes consider actor constellations and networks to be essential determinants (e.g., Duygan et al., 2019). As an example, the widely acknowledged multi-level perspective on socio-technical transitions considers "novel actors" who are not part of the existing regime as a prerequisite to design "radical" innovations that challenge incumbent structures and thus provide impulses for sustainable pathways and transformation (Geels \& Schot, 2007). In addition, the incorporation of actors with conflicting worldviews, which are expressed in values 
and norms but also as future visions, can be used as a criterion to show whether the attempt to grasp the complexity of a sustainability problem is disputed over interests, norms and values; thus, societal embeddedness is acknowledged in innovation design (Schlaile et al., 2017). This means that the description and differentiation of the actors involved in the innovation design and their organization are key in identifying the potential of innovation in regard to contributing towards an SET (Longhurst \& Chilvers, 2019). We use the differentiation of "incumbent" and "novel actors" proposed by Schlaile et al. (2017) to characterize the actors.

\section{Social Learning}

Social learning is defined "as a change in understanding that goes beyond the individual to become situated within wider social units or communities of practice through social interactions between actors within social networks" (Reed et al., 2010 , p. 6). Following this definition, we argue that transformations entail social learning through the reflective uptake of values and norms in terms of a changed understanding through actors. We therefore characterize the likelihood of stimulating social learning through bioeconomic innovation in regard to the following qualitative categories: limited (not very likely to initiate social learning), moderate (likely to stimulate social learning but limited in spatial extent and intensity of change), and high (likely to initiate deep changes in understanding and behaviour).

\section{Changes in the Socio-Technical Regime}

The multi-level-perspective of socio-technical transitions (Geels \& Schot, 2007), although it has been criticized and updated since its development (e.g., Geels, 2019), presents a typology of transition pathways towards socio-technical change. We use this typology to estimate future changes in the socio-technical regime (through the uptake of innovation) that relate to values, beliefs, practices, and behaviours and that could foster sustainability. The transition pathways depend on various factors, such as innovation actors, regime-niche interactions, windows of opportunity, the radicalness of the innovation, and the timing and state of the innovation designs, when changes at the landscape level open up windows of opportunity. In general, changes at the regime level that are produced through transition pathways and the diffusion of innovation can inform changes in norms and values among regime actors (Geels \& Schot, 2007).

\section{Normativity and Innovation}

Innovations and innovation processes are implicitly shaped by and transport normativity, which refers to commonly shared beliefs and imaginaries, hidden convictions, implicit goals and normative orientations (e.g. Jasanoff, 2015; Schmidt, 2007). The normativity of an innovation is interrelated not only with the values and norms reflected by the underlying problem framing but also with ideas about how the innovation should contribute to solving the problem. It also refers to normative beliefs, 
discourses, and imaginaries about the role and function of innovations and innovation processes within society. As an example, modern societies are widely characterized by prevalent techno-optimism -loading innovations with positive associations such as novelty, improvement, societal progress or economic growth, which leads to the perspective of innovations being regarded as per se desirable. In addition to this techno-optimism, there are also more pessimistic connotations associated with innovations that result from an increased perception of risks and ecological damages that have arisen with technological progress. Against this backdrop, the concept of "socially responsible research and innovation" has gained growing attention in recent years (Owen et al., 2012). This concept comprises reflections on the "right impacts" of innovation and considers aspects such as "(ethical) acceptability, sustainability and societal desirability of the innovation process and its marketable products" (Schomberg, 2012).

\section{Innovation Paradigm}

This category summarizes the other categories based on the characterization of bioeconomic innovation as either following the conventional or dedicated innovation paradigm (Schlaile et al., 2017). The conventional paradigm describes the neoclassical culture of sociotechnical innovation as perpetuating economic growth, efficiency, and system improvement that is performed by either incumbent or dominant actors. In contrast, the dedicated innovation paradigm aims to address this norm by including sustainability values in innovation design, focusing on a wider set of actors, acknowledging the wickedness of problems, and incorporating aspects of intra- and intergenerational justice in innovation design.

\section{Case Study: Livestock Production, Manure Issues and Bioeconomic Innovations}

For our analysis, we apply the abovementioned analytical categories to four bioeconomic innovations dealing with manure. The following section first introduces the case of livestock production, briefly describes our approach of applying the analytical categories, presents four selected innovations, and finally shows the results of the analysis.

\section{The Unsustainability of Contemporary Livestock Production}

Managing the global nitrogen cycle within planetary boundaries has been specified to be one of the great challenges of our time (Rockström et al., 2009; Steffen et al., 2015). European countries, and more specifically Germany, are characterized by high nutrient surpluses originating from intensive livestock production and inappropriate fertilizer use (Häußermann et al., 2019). Intensive livestock production has various negative impacts on different sustainability dimensions and at different scales. At the local scale, nitrogen surpluses from agriculture can be leached into 
ground and surface waters, resulting in various negative effects on terrestrial and aquatic ecosystems, including eutrophication, the nitrate pollution of the groundwater and damage to biological diversity (Umweltbundesamt, 2019). Greenhouse gas emissions from livestock production (methane and nitrous oxide) contribute to the global environmental problem of climate change (e.g., Tilman \& Clark, 2014). Examples of societal implications are working conditions in the meat processing industry (e.g., Wagner \& Hassel, 2016), telecoupled effects such as land-use changes for feed production on other continents that can involve conflicts with indigenous people (e.g., Sauer, 2018), and ethical and animal welfare concerns regarding animal husbandry (e.g., Busse et al., 2019).

\section{Potential Solutions Within the Imaginary of a Circular Bioeconomy}

The circular bioeconomy, as proposed by the sociotechnical imaginary of the National Bioeconomy Strategy, is argued to be oriented along natural material cycles and to cover all economic sectors and branches that produce, process, use and trade with renewable resources, such as plants, animals and microorganisms and their products. A particular focus is on residual and waste materials, such as manure, and their cascade use and conversion into value-added products for reuse in agriculture and other sectors (BMEL \& BMBF 2020). Solutions that follow the imaginary of a circular bioeconomy are considered to at least partially close previously open nutrient cycles either farm-internally through cooperation between farms or externally through new value chains alongside perpetuating economic growth (ibid.). We identify four examples of such solutions that can be characterized as bioeconomic innovations based on the definition of such innovations proposed by Bröring et al. (2020), namely, novel manure application techniques (e.g., Darapuneni et al., 2019), crop livestock integration beyond the farm level (e.g., Asai et al., 2018), manure conversion into novel fertilizers (e.g., Pintucci et al., 2017), and manure conversion into new feedstuffs (e.g., Čičková et al., 2015).

Although the abovementioned innovations have been claimed to contribute to a better and circular management of nitrogen, it is unclear whether they contribute to an SET, which we argue is necessary to solve multiple environmental and social crises (cf. Brand et al., 2020; Temper et al., 2018). Thus, we aim to characterize these innovations based on the analytical categories presented in "Socio-Technical Innovations in the Bioeconomy and the Contribution to SET-Developing Analytical Categories" section. We argue that this characterization allows the comparison of the sectoral contribution of a bioeconomy in its current shape to an SET at large by focusing on innovation as an analytical category.

\section{Applying the Analytical Categories to the Case of Animal Production and Manure Utilization}

In the following, we exemplarily apply our analytical categories to the case of manure-based bioeconomic innovation. We choose four manure-based innovations that are designed by different actors and imply different approaches based on the 
Table 1 Information sources for considering the normative dimensions of bioeconomic manure-based innovations

\begin{tabular}{ll}
\hline Innovation & Sources \\
\hline $\begin{array}{l}\text { Novel manure application techniques, i.e., integrating } \\
\text { manure with strip-tillage }\end{array}$ & Darapuneni et al. (2019) \\
Manure exportation to other farms and regions & Vogelsang (2020) \\
& Asai et al. (2018) \\
Agrarhandel Dienstleistungen Nagler (2020) \\
NOnure conversion into recycled fertilizer & Pintucci et al. (2017) \\
& CORDIS (2016) \\
Fioconversion of manure into new feedstuffs, i.e., insect & Frauenhofer IGB (2020) \\
cultivation in manure & SUEZ (2019) \\
& EFSA Scientific Committee (2015) \\
& van Huis (2019) \\
& Hermetia (2020)
\end{tabular}

characterization of bioeconomic innovations (cf. Bröring et al., 2020). Our results are based on a content analysis of available online documents, homepages, and scientific sources in relation to the categories of our analytical categories (see 3 ). Table 1 gives an overview of the analysed sources.

\section{Results: Normative Dimensions of Manure-Based Bioeconomic Innovations}

An overview of the results can be found in Table 2. In the following, we describe our considerations that led us to these results.

\section{Novel Manure Application Techniques: Integrating Manure with Strip-Tillage}

Manure storage and application are a major source of $\mathrm{N}$ emissions. Novel manure application techniques, such as strip-tillage with root-level liquid manure fertilization, are being increasingly practised and promoted, with the aim of reducing ammonia and nitrous oxide emissions (odour, greenhouse gas) during application and improving N-use efficiency (Darapuneni et al., 2019). The innovation is designed by incumbent actors within the socio-technical regime (agricultural machine manufacturer) that develop new ideas. The problem frame is clearly focused on the application of manure and its field-level consequences in the application process. This can be considered a matter of efficiency for which the solution rests in technologies involving more precise application techniques. This new technique could moderately stimulate social learning, and the reduced odour is a directly perceived positive impact for the local population. Nonetheless, the potential changes in the socio-technical regime remain rather narrow in terms of characterization as a reproduction process (Geels \& Schot, 2007), i.e., substituting old technologies with new ones as a way of improving the current system of application. This approach is also 


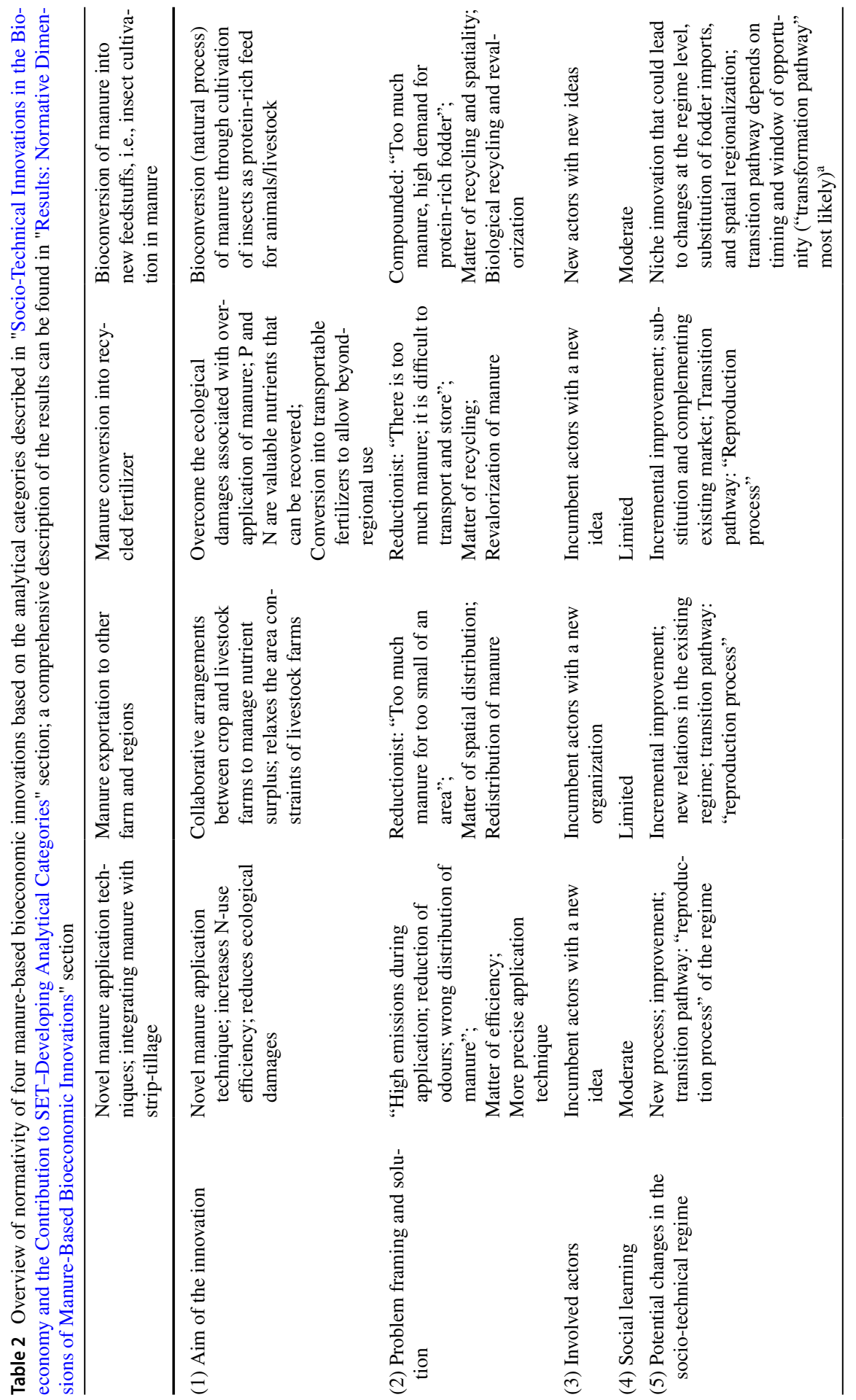




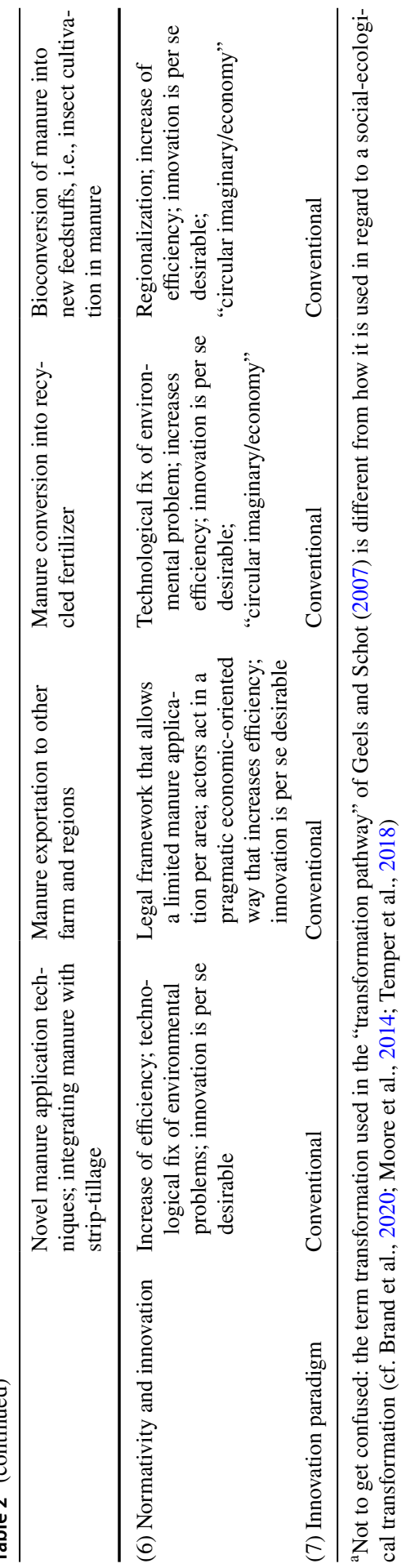


grounded in the value of and belief in a technological fix for environmental problems, the increase of efficiency, and the idea that innovation is per se desirable. This means that although innovation prevents nutrient loss and can improve ecological performance, innovation has been designed by incumbent actors and is thus considered to be following the conventional paradigm (Schlaile et al., 2017). This means that the neoclassical idea of entrepreneurial innovation materializes in novel manure application techniques through its focus on system improvement and efficiency.

\section{Manure Export to Other Farms and Regions}

Through novel collaborative arrangements (e.g., Asai et al., 2018) with arable farmers, livestock farmers seek to reduce their nutrient surpluses, particularly since fertilizer regulations have been tightened. The actors involved in this innovation are mainly farmers from different regions who represent incumbent actors, in addition to logistic companies that transport manure from livestock regions to arable regions. This means that the incumbent actors organize themselves in a new format. The problem is framed in the reductionist way such that there is too much manure for too small of an area following the nitrate directive. This means that manure is a matter of spatial distribution, which becomes explicit in the solution of the spatial redistribution of manure. Although new social relations between existing actors could enhance social learning, the contact is mainly shaped by business purposes and is thus limited in regard to stimulating social learning on a broader scale. In addition, the scope of actors remains rather narrow. The innovation itself provides incremental improvements through new relations of existing structures, for which it can be characterized as a "reproduction process" (Geels \& Schot, 2007). This also means that innovation represents a pragmatic, economic-oriented way of problem solving (and achieving more sustainable agriculture) that is based on values of efficiency and driven by legal frameworks and the idea that innovation is per se desirable without explicitly considering the potential trade-offs, such as increasing carbon dioxide emissions through transport. Against this background, this innovation follows the conventional paradigm (Schlaile et al., 2017) in terms of being driven by legal frameworks and economic competition in a pragmatic problem-oriented way.

\section{Manure Conversion into Recycling Fertilizers}

New technological developments (e.g., Pintucci et al., 2017) enable the conversion of manure into recycled fertilizers. Manure is voluminous and therefore difficult to store and transport, and its nutrient content varies depending on the feeding regime of the livestock and the collection and storage systems (potentially high gaseous $\mathrm{N}$ losses); thus, manure is less manageable for fertilization compared to mineral fertilizers and it bears a higher risk for emissions and leaching. When it is converted into recycled fertilizers, converted manure arguably becomes more storable and easier to transport, and its on-field application is simpler and better steerable. However, the conversion is also energy intensive; thus, the profitability and ecological footprint depend on the energy source used and the oil price development. 
Recycling fertilizers can partially serve as a substitute for conventional mineral fertilizers and their contested production/extraction and value chain against the background of ending phosphorus deposits; on the other hand, they integrate formerly superfluous biomass into new value chains. This innovation is currently developed by multiple actors, including scientific projects, and is introduced in the market by firms. These actors, who have a new idea, mainly represent incumbent structures of waste recycling. Problem framing can be characterized as reductionist, as manure is regarded as a matter of recycling/waste in terms of too much manure being located in some regions, which is difficult to store and transport. Thus, the solution to this problem is to revalorize manure. The stimulation of social learning may be regarded as limited, as only a limited set of actors is involved in the design and adoption of the innovation; in addition, the innovation does not present new values and norms that could reflectively be taken up. On the one hand, this approach is grounded in the potential transition pathway that we argue is most likely the "reproduction process" (Geels \& Schot, 2007), as the innovation includes incremental improvements, the substitution of mineral fertilizer and the completion of the existing market. On the other hand, this approach builds upon the idea of a technological fix for environmental problems (thereby achieving sustainability) that becomes explicit in the innovation design and is thus influenced by the problem framework and the according imagining of a solution. Furthermore, an imaginary of circularity that has its roots in economics is achieved through the increase of efficiency, the focus on growth and the circularity being imagined as a reintroduction into the market. In this way, innovation is regarded as per se desirable. This also means that the implicit innovation paradigm (Schlaile et al., 2017) of recycling fertilizer can be characterized as conventional (see Table 2). This is explained through supply-side driven developments and incumbent actors, entrepreneurial competition in the innovation design and the implicit assumption that innovation is per se desirable.

\section{Bioconversion of Manure into New Feedstuffs: Insect Cultivation on Manure}

The cultivation of insects in manure for feed use (e.g. Čičková et al., 2015; van Huis, 2019) presents a circular, bioconversion approach. Insects cultivated in manure can be fed to livestock in return and thus serve as a substitute for fish meal or soy-based fodder. This innovation is currently under development and is being designed in niches by novel actors, thereby representing a new idea. We argue that the problem framing of this innovation is compounded, as two issues associated with livestock production-manure surplus and the fodder topic-are considered together. This means that the problem is framed as a matter of recycling and spatiality, as the insects could be used as fodder locally (even on the same farm). The solution addresses these two aspects of biological recycling and revalorization. This novel approach, which is being designed by novel actors, may thus stimulate social learning in a moderate way, as new actors with differing values and perceptions are coming into contact with incumbent actors. However, the potential of social learning also rests in the transition pathway and the corresponding changes in the socio-technical regime, which again depend upon the timing of the innovation design and the window of opportunity described through aspects such as legal frameworks. European 
Union legislation poses a significant hurdle, as neither the feeding of manure to farmed insects nor the feeding of insect-based protein to ruminants, swine and poultry is currently allowed (EFSA Scientific Committee, 2015). These developments suggest that a "transformation pathway" (Geels \& Schot, 2007) may be most likely. This normativity follows an imaginary of circularity that is grounded in regionalism (being different from that of recycling fertilizer). This innovation also incarnates values of efficiency and the idea that innovation is per se desirable. This leads to the conclusion that this innovation follows a conventional paradigm (Schlaile et al., 2017), as the design is supply-side driven and based on entrepreneurial competition and efficiency.

\section{Discussion}

The analysis of four bioeconomic manure-based innovations shows that these innovations follow the values, imaginaries, and beliefs of achieving sustainability through efficiency, a technological fix, entrepreneurial competition, and framing innovation as per se desirable. This can be characterized by following the conventional innovation paradigm (Schlaile et al., 2017). As a consequence, we argue that the ability of these innovations in terms of significantly contributing to SET is rather limited, as they do not inherently incarnate changing values and norms.

In the following, we will focus our discussion on the origin of the materializing values, norms and beliefs from both society and science. In return, we will discuss solutions in both science and policy in terms of adjusting bioeconomic innovation design in the context of an SET in the complex and globally entangled agro-food system.

\section{Bioeconomic Innovations and Their Potential Towards a SET}

\section{Manure-Based Innovations Manifest the Existing Thought Styles of Contemporary Societies}

Our analysis of four manure-related innovations shows that the existing cultures and imaginaries of sustainability change through entrepreneurial competition and are driven by the growth, efficiency, technological fixing of environmental problems, and framing innovation as per se desirable that materialize in these innovations. Thus, the following question arises: what constitutes the manifestation of these cultures and imaginaries in innovation currently? We mainly identify two determinants, although there may be many more, on which we focus our discussion, namely, the problem and solution frame and techno-optimism.

\section{Reductionist Problem Framing as an Example of Manifesting Thought Styles}

Based on our analysis and the research of Nightingale et al. (2020), we argue that a major determinant rests in society's perception of the origins, drivers, and complex 
entanglements of environmental problems. Similar to Nightingale et al.'s (2020) analysis of climate change as being societally framed as a biophysical issue, manure is framed as a matter of distribution, efficiency and recycling. Thus, the solution is considered to be found in redistributing manure through more efficient and new technologies that allow for recycling. This also points to a long discussion in sustainability science and other disciplines on the nature-culture dichotomy and naturehuman dualism, which is also regarded as an inherent characteristic of capitalist societies (e.g. Brand \& Wissen, 2018; Fraser \& Jaeggi, 2020; Haraway, 2016; West et al., 2020). This means that instead of framing manure as a product of complex human-nature relations and entanglements, manure is framed in the above-described reductionist manner. These complex entanglements are driven by, in a nutshell, production, consumption, industrialization, and globalization patterns in the agrofood system and result in complex, interdependent, and often telecoupled problems, such as land-use change for fodder production, animal welfare, working conditions, the eutrophication of water bodies, and greenhouse gas emissions (e.g. Foley et al., 2011; Herrero et al., 2020; Tilman \& Clark, 2014; Tscharntke et al., 2012; Wagner \& Hassel, 2016). All these aspects are related to critical issues that require ethical discussions and negotiation processes in the search of a sustainable bioeconomy. In contrast, the solutions that are designed on the basis of the reductionist problem framework thus present a sort of "solutionism" (Morozov, 2013), that is, a technological design aimed at solving a problem whose complexity is not yet understood (see also Markusson et al., 2017). This is not meant to place blame on innovation actors for their technological inventions and innovative designs but rather to highlight the role of societies and sciences in shaping the understanding of the multiple crises in a reductionist, biophysical way rather than through complex political-economic entanglements (see also Markusson et al., 2017).

\section{Prevailing Techno-Optimism is Inherent in Society and Can Lead to Negative Effects for Social-Ecological Systems}

In addition, we argue that the analysis of the four bioeconomic innovations points to techno-optimism in society. This does not mean framing technology in a pessimistic way; rather, we argue for a critical turn in society to acknowledge that sociotechnical innovation can of course have benefits for society and the environment but that the belief in techno-optimism does allocate the power to change to technological solutions rather than a combination of socio-technical, cultural and behavioural solutions; this approach supports business-as-usual strategies and, accordingly, the hope of a "deus ex machina" (cf. Rajak, 2020). Techno-optimism also implies overemphasizing the fallacy that humans are able to fully control environmental processes and has been argued to apply to other sectors as well (e.g. Markusson et al., 2017; Pfotenhaueret al., 2019; Rajak, 2020; Strand et al., 2018). This becomes explicit in the neoliberal belief that innovation, which is often associated with technological invention, is per se desirable (see also Schlaile et al., 2017). However, historical developments have shown that socio-technical innovation can lead to lockins in systems that manifest existing structures (e.g., Klitkou et al., 2015), problem shifting to other sectors (e.g., van den Bergh et al., 2015), unintended trade-offs that 
are uncertain and can play a role in various scales and spatialities through complex relations in the so-called nexus (e.g., Bukkens et al., 2020), or the evergreen rebound effect (e.g., Paul et al., 2019). We argue that framing innovation as per se desirable without critically assessing the potential trade-offs and conflicting values can manifest existing unsustainable practices that are ethically questionable. Giampietro (2019) argued, based on an analysis of global socio-metabolic flows, that tertiary flows (such as manure, or waste in general) depend upon primary energy sources (soil, water, air) and secondary flows (fodder, livestock). This means that manurebased innovations (and bioeconomic innovation in general) could manifest structures of "unsustainable" land use in southern America for fodder production (e.g., Sauer, 2018) and the methane emissions of livestock farms (e.g., Foley et al., 2011), which, if framed as socio-metabolic flows, are the basis for manure-based bioeconomic innovation. In return, this means that the manifestation of thought styles, or a lock-in of capitalist imaginaries, values and norms in society (also policy, as argued by Escobar, 2015), which materialize in socio-technical innovation, has multiple concrete consequences for the sustainability of current social-ecological systems on other scales and could manifest complex unsustainable systems entanglements.

\section{Science Implications: How Can Science Provide Support to Design a Sustainable and Just Bioeconomy?}

In accordance with other scholars (e.g. Bukkens et al., 2020; Daedlow et al., 2016; Funtowicz \& Ravetz, 1993), we consider the reflection on and adaptation of research processes to be key for leveraging a sustainability transformation. Science is also expected to play a central role in shaping the bioeconomy. This assumption is reflected not only in national bioeconomy strategies, such as those found in in Germany (BMEL \& BMBF 2020), but also in specifying concepts such as ideas of a "knowledge-based bioeconomy" (Urmetzer et al., 2018). By setting specific research topics in research programmes, research has become an important implementation tool of the bioeconomy. This approach also reveals how these research programmes want to influence bioeconomic innovation processes and how far they align with the aims and processes of an SET.

For a long time, a focus on techno-economic knowledge and accordingly rather "reductionist" disciplinary perspectives has been dominant in science agendas (Pfotenhauer et al., 2019; Strand et al., 2018). Even if this techno-optimistic perspective continues to prevail, a recent shift towards more systemic and more integrated approaches could be observed. Currently, inter- and transdisciplinary processes are claimed to be important approaches for a sustainable bioeconomy (BMEL \& BMBF 2020).

This is an important and welcome step forward, as it acknowledges that an SET towards a sustainable bioeconomy is a complex, adaptive process in which different and frequently opposite norms and values, interests, world views and target conflicts must be negotiated and harmonized (e.g. Zscheischler \& Rogga, 2015). With regard to the design of a socially desirable and ethically acceptable bioeconomy, similar to an SET, there is no general ethical code that is commonly 
shared by the wider parts of society. Rather, multiple conflicts of interest emerge in evaluating the "proper" use of natural resources with regard to utilitarian and deontological concerns or issues of social justice. For the case of manure, integration thus requires discussing and weighing supposedly antagonistic aspects such as the self-determination of farmers, future generations' right to develop and evolve, animal ethics, or indigenous land rights in Southern America.

Transdisciplinary processes are able to grasp these complexities and allow the integration of ontological pluralism, different perspectives, knowledge types and norms and values by involving diverse actors and interest groups (e.g., Scholz, 2011). Only in this way will scientists be able to provide socially robust, wellaccepted and legitimized orientations for a sustainability transformation. In addition, such integrative approaches enhance the social responsibility of research and innovation (Daedlow et al., 2016; Gremmen et al., 2019). The manure example shows that applying such processes is in great need, as current manure-based bioeconomic innovations are designed by incumbent actors who do not represent the heterogeneity of perspectives, positionalities, and knowledges that are necessary to understand these wicked problems (cf. Schlaile et al., 2017).

\section{Research and Development Projects Should be Embedded in Larger Transdisciplinary Processes}

However, the question of how results from transdisciplinary processes will impact political decisions, bioeconomic research and innovation processes in the future remains unanswered. As long as this issue remains unclarified, the commitment to socially responsible research and transdisciplinary processes may remain a front to appear conscientious. As an example, a comparative study on transdisciplinary research processes has shown that this approach is often misinterpreted by nature scientists as an approach to enhance the acceptability of new technological innovations or is even misused as a kind of "rhetorical mainstreaming" (e.g. Zscheischler et al., 2017). We argue that transdisciplinary processes can help us to better understand and anticipate how and under which conditions a bioeconomic innovation can benefit or harm society.

In addition, transdisciplinary processes can stimulate new innovations by codesigning solutions together with societal actors and scientists from different disciplines that might be different from conventional innovations. This would also be aimed towards the dedicated innovation paradigm (Schlaile et al., 2017). Thus, research and development projects should be embedded in these integrative research processes. However, transdisciplinary processes are time-consuming and require well-trained facilitators, as well as a high degree of flexibility, to meet the high demands with regard to issues of contributive and procedural justice (Timmermann, 2020). It is also challenging to move beyond anthropocentric perspectives and integrate the intrinsic value of non-humans in these processes, such as the environmental concerns related to the overapplication of manure and the according eutrophication of water bodies or the association with soy production for animal fodder. 


\section{Science has the Obligation and Responsibility to Think of More Radical Solutions}

Currently, agriculture in Germany and the EU is associated with many sustainability challenges and is characterized by a strong persistence and lobbyism against SET and the related negotiation processes in society. As an example, Alons (2017) argued that although environmental actors are currently considered in agricultural policy making, this is done to legitimate business-as-usual strategies and not to favour an SET. Many bioeconomic innovations are linked to this nonsustainable system, for example, by looking for new uses for waste and residues from agriculture, as in the case of manure surpluses. We see the risk that many bioeconomic innovations might not only build on unsustainable systems but also contribute to their manifestation.

As a consequence, science should use its "freedom" to develop and try out real radical alternative solutions. This development will need more reflexive and integrative research processes that are normatively oriented towards an SET and acknowledge uncertainty in the future (Bukkens et al., 2020). This also means critically analysing political-economic interventions and configurations that are associated with innovation and prevailing techno-optimism in society (Markusson et al., 2017; Pfotenhauer et al., 2019). Additionally, politics should recognize the possibility of transdisciplinary research to stimulate social learning and contribute to social justice in agricultural innovation and decision-making by applying contributive justice concepts and thus further supporting transformative research processes (see also Rogga et al., 2018). Not least, such development will also necessitate the political will to take up the results in a suitable format and move beyond the instrumental value of public participation for the sake of acceptance of decisions (Stilgoe \& Guston, 2017).

\section{Policy Implications: How Can Policy-Making Support a Sustainable Bioeconomy?}

Politicians depend on democratic elections and operate in distinct time horizons (legislative terms) and thus must take into account and find a balance between multiple interests. Such a setting is generally not particularly suitable for enabling fast and radical changes; rather, it goes along with compromises, second-best solutions, and gradual reforms.

However, policy makers can contribute to a social climate in which addressing the realms proposed by Abson et al. (2017) - to re-think our knowledge production and use, to restructure institutions and to reconnect people with nature-becomes possible, thereby setting the framework and incentives (while reducing the disincentives and barriers) for an SET. A policy mix that could be supportive of an SET may include a combination of the integration of different perspectives and positionalities in decision-making, room and support for niche actors (e.g., start-up capital, real laboratories), adequate incentives at the regime level (e.g., through regulations, positive and negative incentives), and macroeconomics and macropolitics that may also influence the landscape level (e.g., alternative national welfare calculation, effective $\mathrm{CO}_{2}$ pricing). 
From a national perspective on the manure surplus problem, policy makers face a trade-off between allocative (e.g., internalizing negative externalities from stocking rates that are too high) and distributional claims (e.g., mitigating social impacts for livestock farmers by managing transition times and providing alternative income sources), while also having to ensure stabilization (e.g., avoiding drastic changes to prevent countereffects or radicalisation of society against these politics).

\section{Sustainable Governance Needs a Complex Systems Perspective}

Addressing the manure surplus problem from an SET perspective, however, requires a reframing of the problem and a perspective change towards the entire agro-food system, including local, national and international aspects. Recent developments aim at an integrated policy approach that addresses several domains of the agrofood system (WBAE 2020), which may also have impacts on the livestock sector and manure surpluses. In this regard, incremental improvements have already been made with regard to reducing production incentives through the reform of the EU's agricultural policy (the abandonment of export subsidies, the introduction of ecoschemes), mandatory animal welfare standards for livestock farms (e.g., piglet castration, space per animal, use of antibiotics), reformed fertilizer regulation with higher demands and sanctions, and research and support for EU protein crops (for substitution of imported animal feed). Further producer-related measures are currently being discussed, such as a maximum livestock density per land area, as are potential high-impact cross-cutting interventions such as effective $\mathrm{CO}_{2}$ pricing. Consumer-related instruments that have been suggested, for example, by the WBAE (2020), include increasing the value-added tax for meat products (which could result in a further reduction of meat consumption), climate labels for supermarket products (improved information), or mandatory dietary prescriptions for school and kindergarten children. Innovations linking producers and consumers, such as communitysupported agriculture and testing environments for innovation and regulation, such as in transformative research processes (see 5.2), need further attention and support. In the sense of Abson et al. (2017), this could both reconnect humans and nature and encourage rethinking with regard to knowledge production.

\section{Sustainable Bioeconomy Needs Adaptive and Reflective Governance Approaches}

Although the transformation of the agro-food system is perhaps still in an early stage, the above example illustrates how a combination of political instruments allows for the targeting of leverage points at different levels. This approach should be further developed towards integrated systems thinking and following a reflexive governance approach that allows for continuous policy learning and adaptation (Feindt \& Weiland, 2018) and acknowledges uncertainty in complex systems (Bukkens et al., 2020).

Analogously, systems thinking and reflexive and adaptive governance should also guide the further development of bioeconomy strategies to support SETs. The fact that criticism from non-governmental actors has led to a change in the composition of the German bioeconomy council, the introduction of bioeconomy monitoring, 
and a widening of the sustainability perspective of new bioeconomy strategy shows that the development and implementation process of the bioeconomy strategy is generally reflexive. However, there are still important needs for further adjustments, as integration may be due to legitimating business-as-usual strategies (Alons, 2017). Currently, the primary responsibility for the bioeconomic strategy is shared between the BMEL and BMBF. Innovation support (e.g., industrial bioeconomy, real laboratories) is granted by the Federal Ministry for Economic Affairs and Energy (BMWi). Other ministries, such as the environment (UBA) and economic cooperation and development (BMZ), play a less central role, but this role should be intensified given the implications of the bioeconomy for different sectors and regional, national and international scales. We also argue for incorporating the knowledge created by transdisciplinary research processes beyond its instrumental value (see "Science Implications: How Can Science Provide Support to Design a Sustainable and Just Bioeconomy?"section) in regard to the design mission of a social-ecological transformation and the responsibility of policies for societal dialogue and transformation. The uptake of these results and this knowledge also allows us to move towards what has been framed as a dedicated innovation paradigm (Schlaile et al., 2017). This implies acknowledging the wickedness of the problem, which requires multiple actor participation and adaptive governance mechanisms as part of an ethical and responsible approach to an SET. In general, stimulating ethical discourse, including the discussion and consideration of moral dilemmas, on agricultural and bioeconomic innovations and their consequences both within and beyond society is an important step towards producing knowledge concerning how to design a just and sustainable bioeconomy.

\section{Conclusions}

The aim of this article was to identify the contribution of currently developed bioeconomic innovations towards their ability to contribute to an SET. We studied four innovations that aim to reduce nutrient surpluses from intensive livestock production. Based on the argumentation that an SET entails changing values, norms, and imaginaries that are currently present in societies, we developed and applied analytical categories that allowed us to analyse the norms and values that are being both performed and produced in bioeconomic innovation design. The results show that bioeconomic innovations manifest existing dominant thought styles that are based on reductionist problem framing, nature-human dualism, and prevailing techno-optimism. Against this backdrop, science and policy are important actors in both reshaping values and norms and reflecting ethical concerns and principles following the design mission of an SET. We argue that adjusting bioeconomic innovation towards the aims of an SET means highlighting the role of integrative and transformative research approaches that incorporate multiple knowledge and perspectives. In this respect, the role of science in trying out real alternatives as opposed to contemporary cultures of innovation design is important, as politics is trapped between different perspectives. Nevertheless, this needs to be accompanied by the reflective and adaptive governance of systems thinking 
that acknowledges the complex global entanglements of contemporary livestock production alongside the uncertainty of future transformations and their impacts on sustainability. These approaches can support innovation actors and policy makers in developing socio-technical innovations and strategies to cope with multiple crises. Our results are also applicable to other sectors in relation to bioeconomic approaches and SETs at large.

Funding Open Access funding enabled and organized by Projekt DEAL. This publication was made possible by grant agreement 031B0751 from the German Federal Ministry of Education and Research (BMBF).

Open Access This article is licensed under a Creative Commons Attribution 4.0 International License, which permits use, sharing, adaptation, distribution and reproduction in any medium or format, as long as you give appropriate credit to the original author(s) and the source, provide a link to the Creative Commons licence, and indicate if changes were made. The images or other third party material in this article are included in the article's Creative Commons licence, unless indicated otherwise in a credit line to the material. If material is not included in the article's Creative Commons licence and your intended use is not permitted by statutory regulation or exceeds the permitted use, you will need to obtain permission directly from the copyright holder. To view a copy of this licence, visit http://creativecommons.org/licen ses/by/4.0/.

\section{References}

Abson, D. J., Fischer, J., Leventon, J., Newig, J., Schomerus, T., Vilsmaier, U., von Wehrden, H., Abernethy, P., Ives, C. D., Jager, N. W., \& Lang, D. J. (2017). Leverage points for sustainability transformation. Ambio. https://doi.org/10.1007/s13280-016-0800-y

Agrarhandel Dienstleistungen Nagler (2020). Güllebörse. Retrieved 27 Nov 2020 from https://www.futte rboerse-nagler.de/index.php/geschaeftsbereiche/guelleboerse.

Alons, G. (2017). Environmental policy integration in the EU's common agricultural policy: Greening or greenwashing? Journal of European Public Policy. https://doi.org/10.1080/13501763.2017.1334085

Asai, M., Moraine, M., Ryschawy, J., de Wit, J., Hoshide, A. K., \& Martin, G. (2018). Critical factors for crop-livestock integration beyond the farm level: A cross-analysis of worldwide case studies. Land Use Policy. https://doi.org/10.1016/j.landusepol.2017.12.010

Ashukem, J.-C.N. (2020). The SDGs and the bio-economy: Fostering land-grabbing in Africa. Review of African Political Economy. https://doi.org/10.1080/03056244.2019.1687086

Birch, K., Levidow, L., \& Papaioannou, T. (2010). Sustainable Capital? The Neoliberalization of Nature and Knowledge in the European "Knowledge-based Bio-economy." Sustainability. https://doi.org/ $10.3390 / \mathrm{su} 2092898$

BMEL, \& BMBF (2020). Nationale Bioökonomiestrategie: Kabinettversion, 15.01.2020. Retrieved 19 June 2020 from https://www.bmbf.de/files/bio\%c3\%b6konomiestrategie\%20kabinett.pdf.

Brand, U., Görg, C., \& Wissen, M. (2020). Overcoming neoliberal globalization: Social-ecological transformation from a Polanyian perspective and beyond. Globalizations. https://doi.org/10.1080/14747 731.2019.1644708

Brand, U., \& Wissen, M. (2018). The limits to capitalist nature: Theorizing and overcoming the imperial mode of living (Transforming capitalism). Rowman \& Littlefield International.

Bröring, S., Laibach, N., \& Wustmans, M. (2020). Innovation types in the bioeconomy. Journal of Cleaner Production. https://doi.org/10.1016/j.jclepro.2020.121939

Bruckmeier, K., \& Pires, I. (2018). Innovation as transformation: Integrating the socio-ecological perspectives of resilience and sustainability. In H. Pinto, T. Noronha, \& E. Vaz (Eds.), Resilience and Regional Dynamics. Cham: Springer. 
Bugge, M., Hansen, T., \& Klitkou, A. (2016). What is the bioeconomy? A review of the literature. Sustainability. https://doi.org/10.3390/su8070691

Bukkens, S., Dunlop, T., Di Felice, L. J., Kovacic, Z., Nilsen, I. W., Strand, R., Völker, T., \& Zamarioli, L. (2020). The nexus times. Megaloceros Press.

Busse, M., Kernecker, M. L., Zscheischler, J., Zoll, F., \& Siebert, R. (2019). Ethical concerns in poultry production: A German consumer survey about dual purpose chickens. Journal of Agricultural and Environmental Ethics. https://doi.org/10.1007/s10806-019-09806-y

Čičková, H., Newton, G. L., Lacy, R. C., \& Kozánek, M. (2015). The use of fly larvae for organic waste treatment. Waste Management. https://doi.org/10.1016/j.wasman.2014.09.026

CORDIS (2016). Ergebnisse in Kürze. https://cordis.europa.eu/project/id/603744/de.

Daedlow, K., Podhora, A., Winkelmann, M., Kopfmüller, J., Walz, R., \& Helming, K. (2016). Socially responsible research processes for sustainability transformation: An integrated assessment framework. Current Opinion in Environmental Sustainability. https://doi.org/10.1016/j.cosust.2016.09. 004

Darapuneni, M. K., Lauriault, L. M., Dodla, S. K., Idowu, O. J., Grover, K., Martinez, G., Djaman, K., \& Angadi, S. V. (2019). Temporal variations in plant and soil characteristics following strip-till manure application. Soil and Tillage Research. https://doi.org/10.1016/j.still.2019.104350

Duygan, M., Stauffacher, M., \& Meylan, G. (2019). A heuristic for conceptualizing and uncovering the determinants of agency in socio-technical transitions. Environmental Innovation and Societal Transitions. https://doi.org/10.1016/j.eist.2019.02.002

EFSA Scientific Committee. (2015). Risk profile related to production and consumption of insects as food and feed. EFSA Journal. https://doi.org/10.2903/j.efsa.2015.4257

El-Chichakli, B., von Braun, J., Lang, C., Barben, D., \& Philp, J. (2016). Policy: Five cornerstones of a global bioeconomy. Nature. https://doi.org/10.1038/535221a

Escobar, A. (2015). Degrowth, postdevelopment, and transitions: A preliminary conversation. Sustainability Science. https://doi.org/10.1007/s11625-015-0297-5

Feindt, P. H., \& Weiland, S. (2018). Reflexive governance: exploring the concept and assessing its critical potential for sustainable development-Introduction to the special issue. Journal of Environmental Policy \& Planning. https://doi.org/10.1080/1523908X.2018.1532562

Foley, J. A., Ramankutty, N., Brauman, K. A., Cassidy, E. S., Gerber, J. S., Johnston, M., Mueller, N. D., O’Connell, C., Ray, D. K., West, P. C., \& Balzer, C. (2011). Solutions for a cultivated planet. Nature. https://doi.org/10.1038/nature10452

Fraser, N., \& Jaeggi, R. (2020). Kapitalismus: Ein Gespräch über kritische Theorie (suhrkamp taschenbuch wissenschaft).

Frauenhofer IGB (2020). BioEcoSIM: Nachhaltige Aufbereitung von Gülle. Retrieved 27 Nov 2020 from https://www.igb.fraunhofer.de/de/forschung/wasser-abwasser/naehrstoffmanagement/proje kte/bioecosim.html.

Funtowicz, S. O., \& Ravetz, J. R. (1993). Science for the post-normal age. Futures. https://doi.org/10. 1016/0016-3287(93)90022-L

Geels, F. W. (2002). Technological transitions as evolutionary reconfiguration processes: A multilevel perspective and a case-study. Research Policy. https://doi.org/10.1016/S0048-7333(02) 00062-8

Geels, F. W. (2019). Socio-technical transitions to sustainability: A review of criticisms and elaborations of the Multi-Level Perspective. Current Opinion in Environmental Sustainability. https:// doi.org/10.1016/j.cosust.2019.06.009

Geels, F. W., \& Schot, J. (2007). Typology of sociotechnical transition pathways. Research Policy. https://doi.org/10.1016/j.respol.2007.01.003

Giampietro, M. (2019). On the circular bioeconomy and decoupling: Implications for sustainable growth. Ecological Economics. https://doi.org/10.1016/j.ecolecon.2019.05.001

Gorddard, R., Colloff, M. J., Wise, R. M., Ware, D., \& Dunlop, M. (2016). Values, rules and knowledge: Adaptation as change in the decision context. Environmental Science \& Policy. https://doi. org/10.1016/j.envsci.2015.12.004

Gremmen, B., Blok, V., \& Bovenkerk, B. (2019). Responsible innovation for life: Five challenges agriculture offers for responsible innovation in agriculture and food, and the necessity of an ethics of innovation. Journal of Agricultural and Environmental Ethics. https://doi.org/10.1007/ s10806-019-09808-w

Haraway, D. J. (2016). Staying with the trouble: Making kin in the Chthulucene (Experimental futures Technological lives, scientific arts, anthropological voices). Duke University Press. 
Häußermann, U., Bach, M., Klement, L., \& Breuer, L. (2019). Stickstoff-Flächenbilanzen für Deutschland mit Regionalgliederung Bundesländer und Kreise: Jahre 1995 bis 2017 (Texte 131). Dessau-Roßlau. Retrieved 29 June 2020 from https://www.umweltbundesamt.de/sites/ default/files/medien/1410/publikationen/2019-10-28_texte_131-2019_stickstoffflaechenbilanz. pdf.

Hermetia (2020). Hermetia. Retrieved 27 November 2020 from http://www.hermetia.de/.

Herrero, M., Thornton, P. K., Mason-D’Croz, D., Palmer, J., Benton, T. G., Bodirsky, B. L., Bogard, J. R., Hall, A., Lee, B., Nyborg, K., \& Pradhan, P. (2020). Innovation can accelerate the transition towards a sustainable food system. Nature Food. https://doi.org/10.1038/s43016-020-0074-1

Hertel, T., Steinbuks, J., \& Baldos, U. (2013). Competition for land in the global bioeconomy. Agricultural Economics. https://doi.org/10.1111/agec.12057

Hickel, J., \& Kallis, G. (2020). Is Green Growth Possible? New Political Economy. https://doi.org/10. $1080 / 13563467.2019 .1598964$

Hirsch Hadorn, G., \& Jäger, J. (2008). Handbook of transdisciplinary research. Springer.

Hölscher, K., Wittmayer, J. M., \& Loorbach, D. (2018). Transition versus transformation: What's the difference? Environmental Innovation and Societal Transitions. https://doi.org/10.1016/j.eist.2017.10. 007

Jahn, T., Hummel, D., Drees, L., Liehr, S., Lux, A., Mehring, M., Stieß, I., Völker, C., Winker, M., \& Zimmermann, M. (2020). Sozial-ökologische Gestaltung im Anthropozän. GAIA Ecological Perspectives for Science and Society. https://doi.org/10.14512/gaia.29.2.6

Jander, W., Wydra, S., Wackerbauer, J., Grundmann, P., \& Piotrowski, S. (2020). Monitoring bioeconomy transitions with economic-environmental and innovation indicators: Addressing data gaps in the short term. Sustainability. https://doi.org/10.3390/su12114683

Jasanoff, S. (2015). Imagined and Invented Worlds. In S. Jasanoff (Ed.), Dreamscapes of modernity: Sociotechnical imaginaries and the fabrication of power. University of Chicago Press.

Jasanoff, S. (2016). The ethics of invention: Technology and the human future (The Norton global ethics series). W.W. Norton \& Company.

Jasanoff, S., \& Kim, S.-H. (2009). Containing the Atom: Sociotechnical Imaginaries and Nuclear Power in the United States and South Korea. Minerva. https://doi.org/10.1007/s11024-009-9124-4

Klitkou, A., Bolwig, S., Hansen, T., \& Wessberg, N. (2015). The role of lock-in mechanisms in transition processes: The case of energy for road transport. Environmental Innovation and Societal Transitions. https://doi.org/10.1016/j.eist.2015.07.005

Loiseau, E., Saikku, L., Antikainen, R., Droste, N., Hansjürgens, B., Pitkänen, K., Leskinen, P., Kuikman, P., \& Thomsen, M. (2016). Green economy and related concepts: An overview. Journal of Cleaner Production. https://doi.org/10.1016/j.jclepro.2016.08.024

Longhurst, N., \& Chilvers, J. (2019). Mapping diverse visions of energy transitions: Co-producing sociotechnical imaginaries. Sustainability Science. https://doi.org/10.1007/s11625-019-00702-y

Markusson, N., Gjefsen, M. D., Stephens, J. C., \& Tyfield, D. (2017). The political economy of technical fixes: The (mis)alignment of clean fossil and political regimes. Energy Research \& Social Science. https://doi.org/10.1016/j.erss.2016.11.004

Max-Neef, M. A. (2005). Foundations of transdisciplinarity. Ecological Economics. https://doi.org/10. 1016/j.ecolecon.2005.01.014

Moore, M.-L., Tjornbo, O., Enfors, E., Knapp, C., Hodbod, J., Baggio, J. A., Norström, A., Olsson, P., \& Biggs, D. (2014). Studying the complexity of change: Toward an analytical framework for understanding deliberate social-ecological transformations. Ecology and Society. https://doi.org/10.5751/ ES-06966-190454

Morozov, E. (2013). Smarte neue Welt: Digitale Technik und die Freiheit des Menschen (1st ed.). Karl Blessing Verlag.

Nightingale, A. J., Eriksen, S., Taylor, M., Forsyth, T., Pelling, M., Newsham, A., Boyd, E., Brown, K., Harvey, B., Jones, L., \& Bezner Kerr, R. (2020). Beyond technical fixes: Climate solutions and the great derangement. Climate and Development. https://doi.org/10.1080/17565529.2019.1624495

NOM GmbH (2020). Home. https://nom-gmbh.jimdosite.com/.

O'Brien, K. L., \& Wolf, J. (2010). A values-based approach to vulnerability and adaptation to climate change. Wiley Interdisciplinary Reviews: Climate Change. https://doi.org/10.1002/wcc.30

Owen, R., Macnaghten, P., \& Stilgoe, J. (2012). Responsible research and innovation: From science in society to science for society, with society. Science and Public Policy. https://doi.org/10.1093/ scipol/scs093 
Paul, C., Techen, A.-K., Robinson, J. S., \& Helming, K. (2019). Rebound effects in agricultural land and soil management: Review and analytical framework. Journal of Cleaner Production. https://doi.org/ 10.1016/j.jclepro.2019.04.115

Pfotenhauer, S. M., Juhl, J., \& Aarden, E. (2019). Challenging the "deficit model” of innovation: Framing policy issues under the innovation imperative. Research Policy, 48(4), 895-904. https://doi.org/10. 1016/J.RESPOL.2018.10.015

Pintucci, C., Carballa, M., Varga, S., Sarli, J., Peng, L., Bousek, J., Pedizzi, C., Ruscalleda, M., Tarragó, E., Prat, D., \& Colica, G. (2017). The Manure EcoMine pilot installation: advanced integration of technologies for the management of organics and nutrients in livestock waste. Water science and technology: a journal of the International Association on Water Pollution Research. https://doi.org/ 10.2166/wst.2016.559

Pohl, C., \& Hirsch Hadorn, G. (2008). Methodological challenges of transdisciplinary research. Natures Sciences Sociétés. https://doi.org/10.1051/nss:2008035

Rajak, D. (2020). Waiting for a deus ex machina: 'Sustainable extractives' in a $2{ }^{\circ} \mathrm{C}$ world. Critique of Anthropology. https://doi.org/10.1177/0308275X20959419

Reed, M., Evely, A., Cundill, G., Fazey, I., Glass, J., Laing, A., Newig, J., Parrish, B., Prell, C., Raymond, C., \& Stringer, L. C. (2010). What is social learning? Ecology and Society. https://doi.org/10.5751/ ES-03564-1504r01

Rockström, J., Steffen, W., Noone, K., Persson, Å., Chapin, F. S., Lambin, E., Lenton, T. M., Scheffer, M., Folke, C., Schellnhuber, H. J., \& Nykvist, B. (2009). Planetary boundaries: Exploring the safe operating space for humanity. Ecology and Society. https://doi.org/10.5751/ES-03180-140232

Rogga, S., Zscheischler, J., \& Gaasch, N. (2018). How much of the real-world laboratory is hidden in current transdisciplinary research? GAIA - Ecological Perspectives for Science and Society. https://doi. org/10.14512/gaia.27.S1.6

Sanz-Hernández, A., Esteban, E., \& Garrido, P. (2019). Transition to a bioeconomy: Perspectives from social sciences. Journal of Cleaner Production. https://doi.org/10.1016/j.jclepro.2019.03.168

Sauer, S. (2018). Soy expansion into the agricultural frontiers of the Brazilian Amazon: The agribusiness economy and its social and environmental conflicts. Land Use Policy. https://doi.org/10.1016/j. landusepol.2018.08.030

Schlaile, M., Urmetzer, S., Blok, V., Andersen, A., Timmermans, J., Mueller, M., Fagerberg, J., \& Pyka, A. (2017). Innovation systems for transformations towards sustainability? Taking the normative dimension seriously. Sustainability. https://doi.org/10.3390/su9122253

Schmidt, J. C. (2007). Normativity and Innovation: An Approach to Concepts of Innovation from the Perspective of Philosophy of Technology. In S. E. Cozzens (Ed.). In Atlanta Conference on Science, Technology, and Innovation Policy 2007, Atlanta, GA, 10/19/2007 - 10/20/2007 (pp. 1-8). Piscataway, NJ: IEEE. https://doi.org/10.1109/ACSTIP.2007.4472880.

Scholz, R. W. (2011). Environmental literacy in science and society. Cambridge University Press.

Steffen, W., Richardson, K., Rockstrom, J., Cornell, S. E., Fetzer, I., Bennett, E. M., Biggs, R., Carpenter, S. R., de Vries, W., de Wit, C. A., Folke, C., Gerten, D., Heinke, J., Mace, G. M., Persson, L. M., Ramanathan, V., Reyers, B., \& Sorlin, S. (2015). Sustainability: Planetary boundaries-Guiding human development on a changing planet. Science. https://doi.org/10.1126/science.1259855

Stilgoe, J., \& Guston, D. H. (2017). Responsible Research and Innovation. In U. Felt, R. Fouché, C. A. Miller, \& L. Smith-Doerr (Eds.), The handbook of science and technology studies (pp. 853-880). The MIT Press.

Stirling, A. (2014). Emancipating Transformations: From controlling 'the transition' to culturing plural radical progress. Brighton. Retrieved 16 June 2020 from https://steps-centre.org/wp-content/uploa ds/Transformations.pdf.

Strand, R., Saltelli, A., Giampietro, M., Rommetveit, K., \& Funtowicz, S. (2018). New narratives for innovation. Journal of Cleaner Production. https://doi.org/10.1016/j.jclepro.2016.10.194

Strøm-Andersen, N. (2019). Incumbents in the transition towards the bioeconomy: The role of dynamic capabilities and innovation strategies. Sustainability. https://doi.org/10.3390/su11185044

SUEZ (2019). SUEZ plant flächendeckende Aufbereitung von Gülle und Biogasgärresten. Retrieved 27 November 2020 from https://www.suez-recircle.de/themen/suez-plant-flaechendeckende-aufbereitu ng-von-guelle-und-biogasgaerresten.

Temper, L., Walter, M., Rodriguez, I., Kothari, A., \& Turhan, E. (2018). A perspective on radical transformations to sustainability: Resistances, movements and alternatives. Sustainability Science. https://doi.org/10.1007/s11625-018-0543-8 
Tilman, D., \& Clark, M. (2014). Global diets link environmental sustainability and human health. Nature. https://doi.org/10.1038/nature13959

Timmermann, C. (2020). Social justice and agricultural innovation (The international library of environmental, agricultural and food ethics). Springer.

Tomei, J., \& Helliwell, R. (2016). Food versus fuel? Going beyond biofuels. Land Use Policy. https://doi. org/10.1016/j.landusepol.2015.11.015

Tscharntke, T., Clough, Y., Wanger, T. C., Jackson, L., Motzke, I., Perfecto, I., Vandermeer, J., \& Whitbread, A. (2012). Global food security, biodiversity conservation and the future of agricultural intensification. Biological Conservation. https://doi.org/10.1016/j.biocon.2012.01.068

Umweltbundesamt (2019). Nährstoffeinträge aus der Landwirtschaft und Stickstoffüberschuss. Retrieved 29 June 2020 from https://www.umweltbundesamt.de/daten/land-forstwirtschaft/naehrstoffeintr aege-aus-der-landwirtschaft\#stickstoffuberschuss-der-landwirtschaft.

Urmetzer, S., Schlaile, M., Bogner, K., Mueller, M., \& Pyka, A. (2018). Exploring the dedicated knowledge base of a transformation towards a sustainable bioeconomy. Sustainability. https://doi.org/10. 3390/su10061694

van den Bergh, J., Folke, C., Polasky, S., Scheffer, M., \& Steffen, W. (2015). What if solar energy becomes really cheap? A thought experiment on environmental problem shifting. Current Opinion in Environmental Sustainability. https://doi.org/10.1016/j.cosust.2015.05.007

van Huis, A. (2019). Manure and flies: Biodegradation and/or bioconversion? Journal of Insects as Food and Feed. https://doi.org/10.3920/JIFF2019.x002

Vogelsang (2020). Advanced Strip Till Technology. Retrieved 27 November 2020 from https://www. vogelsang.info/index.php?eID $=$ dumpFile $\& \mathrm{t}=\mathrm{f} \& \mathrm{f}=2845 \&$ token $=928 \mathrm{c} 934 \mathrm{c} 9 \mathrm{ad} 18 \mathrm{f} 6340907514 \mathrm{c}$ $174221843 \mathrm{afa} 07 \mathrm{c}$

von Schomberg, R. (2012). Prospects for technology assessment in a framework of responsible research and innovation. In M. Dusseldorp \& R. Beecroft (Eds.), Technikfolgen abschätzen lehren: Bildungspotenziale transdisziplinärer Methoden (pp. 39-61). Springer.

Wagner, B., \& Hassel, A. (2016). Posting, subcontracting and low-wage employment in the German meat industry. Transfer: European Review of Labour and Research. https://doi.org/10.1177/1024258916 636012

Walker, G. (2012). Environmental justice: Concepts, evidence and politics. Routledge.

WBAE (Wissenschaftliche Beirat für Agrarpolitik, Ernährung und gesundheitlichen Verbraucherschutz) (2020). Politik für eine nachhaltigere Ernäh-rung: Eine integrierte Ernährungspolitik entwickeln und faire Ernährungsumge-bungen gestalten: Gutachten. Berlin. Retrieved 20 Nov 2020 from https://www.bmel.de/SharedDocs/Downloads/DE/_Ministerium/Beiraete/agrarpolitik/wbae-gutac hten-nachhaltige-ernaehrung.pdf?_blob=publicationFile \&v=3.

West, S., Haider, L. J., Stålhammar, S., \& Woroniecki, S. (2020). A relational turn for sustainability science? Relational thinking, leverage points and transformations. Ecosystems and People. https://doi. org/10.1080/26395916.2020.1814417

Wiek, A. (2007). Challenges of transdisciplinary research as interactive knowledge generation: Experiences from transdisciplinary case study research. GAIA - Ecological Perspectives for Science and Society. https://doi.org/10.14512/gaia.16.1.14

Zscheischler, J., \& Rogga, S. (2015). Transdisciplinarity in land use science: A review of concepts, empirical findings and current practices. Futures. https://doi.org/10.1016/j.futures.2014.11.005

Zscheischler, J., Rogga, S., \& Busse, M. (2017). The adoption and implementation of transdisciplinary research in the field of land-use science: A comparative case study. Sustainability. https://doi.org/10. $3390 /$ su9111926

Publisher's Note Springer Nature remains neutral with regard to jurisdictional claims in published maps and institutional affiliations. 